\title{
СУТНІСНА ХАРАКТЕРИСТИКА КОМУНІКАТИВНОГО АСПЕКТУ У ВИВЧЕННІ ІНОЗЕМНОЇ МОВИ СТУДЕНТАМИ-МЕДИКАМИ
}

\author{
Н. І. Слагіна \\ ДВНЗ “Тернопільський держсавний медичнийуніверситет імені І. Я. Горбачевського МОЗ Украйни”
}

\section{CHARACTERISTIC FEATURES OF THE COMMUNICATIVE ASPECTS OF FOREIGN LANGUSGE LEARNING BY MEDICAL STUDENTS}

\author{
N. I. Yelagina \\ SHEI "Ternopil State Medical University by I. Ya. Horbachevsky of MPH of Ukraine"
}

\begin{abstract}
У статті проаналізовано психологічні аспекти усного мовлення; охарактеризовано комунікативні та психологічні особливості викладання діалогічного мовлення на заняттях з англійської мови у вищих медичних закладах освіти; розглянуто лінгвістичні характеристики основних функціональних типів діалогів. Визначено основні тенденції та проблеми, пов'язані 3 навчанням усного мовлення 3 іноземної мови студентів-медиків у ситуаціях професійно-зорієнтованого спілкування.
\end{abstract}

The given article analyzes the psychological aspects of oral speech, reveals the communicative and psychological peculiarities of dialogue speech teaching in higher medical educational establishments. The linguistic characteristics of the main functional types of dialogues are also defined. The main tendencies and issues related to teaching foreign language oral speech by medical students in situations of a professionally oriented communication are determined in the given article.

Вступ. Проблема викладання іноземної мови на сучасному етапі розвитку вищої медичної освіти $\epsilon$ особливо актуальною, оскільки зміни, які відбуваються у сфері освіти, все чіткіше зорієнтовуються на вільний розвиток особистості майбутнього фахівця, його самостійність, конкурентоспроможність і мобільність. Відомо, що основною метою мовного навчання студентів у вищому медичному навчальному закладі є підготовка такого фахівця, практичне володіння іноземною мовою якого дозволило б йому ефективно працювати зі спеціалізованими іншомовними джерелами, спілкуватися з колегами, розуміти лекційний матеріал, який спрямований на щоденне та професійне спілкування, складати наукові доповіді. Відповідно до вимог програми однією з практичних цілей навчання іноземної мови є оволодіння навичками та вміннями іншомовного усного мовлення.

У вітчизняній та зарубіжній науці і практиці за останні роки накопичено позитивний досвід навчання усного мовлення на заняттях англійської мови у різноманітних ланках системи підготовки кадрів (Б. Бєляєв, І. Бім, В. Бухбіндер, Н. Гез, Н. Жинкін, І. Зимняя, О. Кірілова, В. Літтлвуд, М. Ляховицький, А. Маркова, О. Миролюбов, С. Ніколаєва, Д. Норман, Ю. Пасов, Н. Скляренко та ін.).

(C) Н. І. Слагіна
Мета статті полягає в аналізі основних тенденцій та проблем, пов'язаних із навчанням усного мовлення $з$ іноземної мови студентів-медиків у ситуаціях професійно-зорієнтованого спілкування.

Для досягнення поставленої мети необхідно реалізувати такі завдання: проаналізувати психологічні аспекти усного мовлення з іноземної мови; охарактеризувати комунікативні та психологічні особливості викладання діалогічного мовлення на заняттях 3 англійської мови у вищих медичних закладах освіти; розглянути лінгвістичні характеристики основних функціональних типів діалогів.

Основна частина. Під поняттям “іншомовне мовлення" розуміють спосіб формування та формулювання думки засобами іноземної мови. Мова і мовлення в такій інтерпретації об'єднуються в ціле як засоби і способи реалізації різних видів мовленнєвої діяльності з метою спілкування [4].

Успіх у навчанні усного іншомовного мовлення значною мірою залежить від того, наскільки повними $є$ наші уявлення про цю форму мовної комунікації, що ми вкладаємо в поняття “усне мовлення". Термін “усне мовлення” характеризується великою ємністю [20]. Багато різноманітних мовленнєвих актів і подій підпадають під цей термін.

Говоріння забезпечує усне спілкування іноземною мовою в діалогічній (паралельно з аудіюванням) i 
монологічній формах і спрямоване до однієї або до великої кількості осіб. Як і будь-яка інша діяльність, акт говоріння завжди має певну мету, мотив, в основі якого лежить потреба; предмет - думки того, хто говорить, продукт - висловлювання (діалог або монолог) і результат, який може виражатися у вербальній або невербальній реакції на висловлювання [11].

Щоб глибше зрозуміти процес усного спілкування, потрібно правильно розуміти процес формування усного мовленнєвого висловлювання.

У методиці викладання іноземних мов розрізняють внутрішнє та зовнішнє мовлення. Внутрішнє мовлення - це еліптичне, побудоване за принципом конспекту мовлення; йому притаманна згорнутість, воно не озвучене. Зовнішнє мовлення - мовлення, де сформоване висловлювання втілюється шляхом артикуляції та інтонування [11].

Усне мовленнєве висловлювання починається 3 мотиву висловлювання, що позначає початковий момент породження мовлення, і відповідно - комунікативний намір того, хто говорить. Комунікативний намір визначає роль мовця як учасника спілкування, конкретну мету його висловлювання [16]. На цьому рівні мовець уже знає, про що говорить, у нього виникає загальний задум майбутнього висловлювання, який не має ще свого мовного втілення, але вже існує у предметно-зображувальному коді. Оформлення задуму здійснюється шляхом відбору мовних засобів, граматичних структур, слів, який реалізується спочатку у внутрішньому мовленні, коли створюється потенційна мовленнєва схема висловлювання. При безпосередньому повідомленні своїх думок у момент їх виникнення вираженню у зовнішньому мовленні передує поява мовленнєвомоторних імпульсів, які, хоча б на частку секунди, випереджають вимову слів. Процес породження усного висловлювання супроводжується слуховим контролем, завдяки чому постійно здійснюється зворотний зв' язок, що приводить висловлювання у відповідність до задуму.

П. Панова зазначає, що мовний зв'язок має три базові ланки:

- ланку орієнтування;

- ланку планування або програмування;

- ланку реалізації програми у мовному коді [16].

Для реалізації програми засобами мови поєднано декілька механізмів: порівняння, вибір, набір (зіставлення) цілого з елементів, комбінування перестановка (заміна), варіації за аналогією [4], прогнозування, дискурсивності [11].

С. Ніколаєва вважає, що найбільш загальними механізмами двостороннього процесу мовленнєвого спілкування є механізми прийому і видачі повідомлення, усередині яких знаходяться механізми:

- осмислення: в єдності аналізу та синтезу, що проявляються по-різному на різних рівнях смислової обробки мовного матеріалу;

- пам'яті: в єдності довготривалої постійної пам'яті та короткочасної оперативної пам'яті;

- випереджаючого синтезу, без якого неможливе жодне висловлювання [11].

Н. Жинкін звертає увагу на процеси осмислення, утримання в пам'яті, випередження, оскільки вони $є$ тими внутрішніми механізмами, за допомогою яких реалізується діяльність основного операційного механізму мовлення, як єдності двох ланок: складання слів з елементів; складання фраз із слів [3].

При розгляді загальних механізмів мовленнєвого спілкування зацікавленість викликає розгляд окремих механізмів говоріння та аудіювання. С. Ніколаєва акцентує увагу на структуру аудіювання, як і говоріння, які складаються $з$ трьох частин:

- спонукально-мотиваційної, яка не тільки визначається потребами слухача, але й опосередковується діяльністю говоріння іншого учасника спілкування;

- аналітико-синтетичної частини, що включає кілька етапів обробки почутого мовленнєвого сигналу та забезпечується такими операціями внутрішнього оформлення, як відбір, зіставлення і встановлення внутрішньопонятійних відповідностей;

- виконавчої частини, яка зумовлює і забезпечує прийняття рішення на основі аналізу і синтезу [11].

Найпростішим механізмом мовлення є механізм відтворення, або репродукції. Репродукція може бути: повна, де використовуються готові ключові фрази, взяті з тексту без змін, для передачі нового змісту; часткова - це репродукція - трансформація, передача змісту в нових формах.

Наступним механізмом говоріння є механізм вибору [10]. Розрізняють вибір слів і вибір граматичної структури.

Механізм репродукування і вибору підпорядковані механізму комбінування, який передбачає таке формування словосполучень і фраз, коли мовець використовує знайомі йому мовні компоненти в нових сполученнях. Від якості сформованості механізму комбінування залежать такі ознаки мовленнєвого вміння говоріння, як продуктивність, новизна, швидкість [11].

Механізм конструювання. У процесі говоріння деякі мовленнєві одиниці конструюються, але, на думку Ю. Пасова, здійснюється це не на основі актуального усвідомлення мовних правил, а на основі аналогії 3 певною абстрактною моделлю, що зберігається в мозку людини, на основі відчуття мови [17]. 
Важливим при усному мовленні $€$ механізм прогнозування (або антиципації), який реалізується у двох напрямках: структурному, де антиципація можлива на рівні фрази; та смисловому, де прогнозування є передбаченням того, чим завершиться ситуація мовлення.

Механізм дискурсивності керує процесом функціонування мовленнєвого висловлювання і працює на рівні актуального усвідомлення [11].

Характерними психологічними рисами усного мовлення є також вмотивованість, направленість, емоційність, ситуативність. Міра емоційності і ситуативності усного мовлення безумовно вища тієї, яка може спостерігатись у письмовому тексті, який навіть описує ситуації усного спілкування. Це пояснюється безпосередньою контактністю усного мовного акту, відсутнього у сфері спілкування писемного мовлення [7].

Для формування мовленнєвих навичок та розвитку вмінь усного мовлення вагому роль відіграє така його риса, як ситуативність, до тогожподвійна ситуативність, коли при породженні репліки-відповіді враховується не тільки наявність екстралінгвістичної мовленнєвої ситуації, яка викликає додатковий мотив до реагування [7].

Велике значення в психологічному плані набуває фактор підготовленості і непідготовленості висловлювання. Підготовлене висловлення завжди базується на вольових зусиллях, на цілеспрямованому довільному запам'ятовуванні мовного матеріалу, на імітуванні, якщо для підготовки використовуються звукові зразки [14]. Непідготовленим висловлюванням можна вважати таке, у якому використовується нова комбінація відомих мовних одиниць; непідготовленим можна його вважати і тоді, коли студент правильно використовує мовний матеріал у цілковито новій ситуації [20].
Зазначені психологічні аспекти усного мовлення важливі при розгляді комунікативних та психологічних особливостей діалогічного мовлення як однієї 3 форм говоріння, що забезпечує усне спілкування іноземною мовою студентів-медиків.

Питанням навчання діалогічного мовлення займалось чимало методистів $[1,5,10,14,18,21,23]$. В цих дослідженнях зазначається, що діалогічне мовлення характеризується певними комунікативними, психологічними та лінгвістичними особливостями.

Під “діалогічним мовленням” розуміють об'єднане ситуативно-тематичною єдністю і комунікативними мотивами поєднання усних висловлювань, послідовно породжених двома і більше співрозмовниками в безпосередньому акті спілкування [15].

А. Маркова зазначає, що діалогічне мовлення виконує такі комунікативні функції:

1) запиту інформації-повідомлення інформації;

2) пропозиції (у формі прохання, наказу, поради)прийняття (неприйняття запропонованого);

3) обміну судженнями (думками, враженнями);

4) взаємопереконання (обгрунтування своєї точки зору) [8].

Діалогічне мовлення слід розглядати як комунікативний акт, де відбувається зміна ролей між співрозмовниками [18]. В діалозі двоє співрозмовників постійно міняють свої комунікативні функції, що внутрішньо виражається в перехопленні ініціативи то даним, то іншим співрозмовником. Таким чином, в натуральному діалозі весь комплекс мовленнєвої ситуації знаходиться у стані “пульсації”, тобто періодичної зміни акценту з контуру A - C на контур B - C і навпаки (рис. 1) [6].
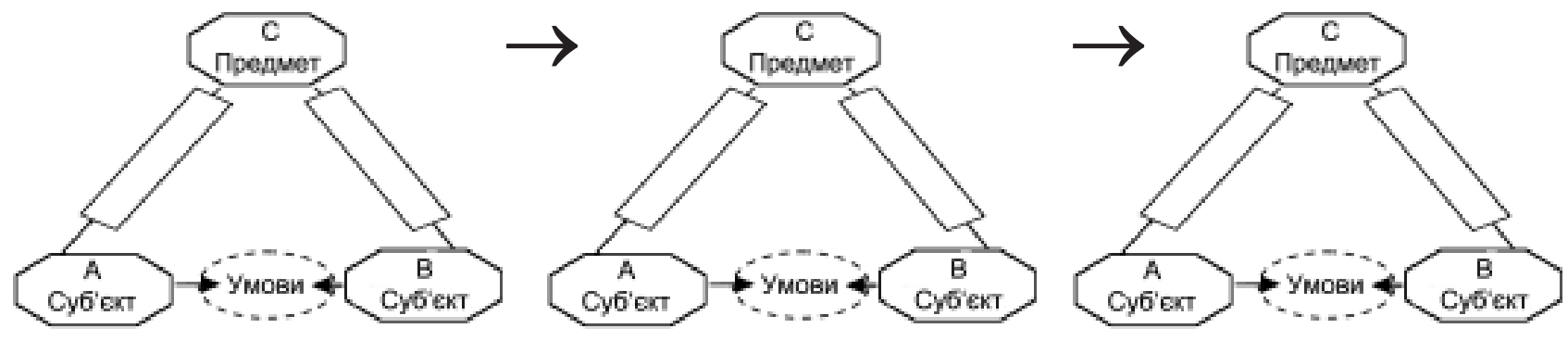

Рис. 1. Активність різних контурів у процесі діалогічного мовлення.

3 комунікативно-ініціативної точки зору, перші репліки (ініціативні) можуть бути зведені до таких типів висловлювань: формули соціального спілкування (привітання, висловлювання вдячності, вибачення тощо); запит інформації (запитання, прохання повідомити щонебудь); вираження емоцій; інформування; наказ прохання; коментування обставин, у яких знаходять- ся співрозмовники; висловлювання фактичного характеру, тобто слів-заповнювачів [2].

Зацікавлення викликає діалогічне мовлення з психологічної точки зору. На зміст та характер діалогічного спілкування впливають такі психологічні аспекти:

1) процес сприйняття мовлення співрозмовника i орієнтації у ситуації; 
2) процеси формування змістовної сторони висловлювання;

3) процеси мовного оформлення думки та сприйняття (+ декодування) реплік партнера по розмові [4].

Контактність співрозмовників $є$ першою особливістю діалогічного мовлення. Початкове висловлювання значною мірою обумовлюється особистістю співрозмовника (як компонента ситуації спілкування), його ставленням до того, хто говорить, компетентністю у розв'язанні обговорюваних проблем, комунікативним зв'язком партнерів, характером їхнього знайомства [6]. Особистість співрозмовника впливає на того, хто починає діалог, сприяє його побудові у психофізіологічному відношенні, налаштовує на певний емоційний лад, що і викликає “запуск” механізмів розумово-інтенційного рівня.

Починаючи діалог, перший його учасник (П.1) оцінює комунікативні можливості партнера, орієнтується в ситуації і на цій основі складає свою мовленнєву програму, актуалізує свої мовленнєві наміри та тему. Другий співрозмовник (П.2), сприйнявши мовленнєве вираження, аналізує його і вимовляє реактивну репліку, враховуючи при цьому особистість того, хто почав діалог, та обстановку, власні наміри та мотиви (рис. 2) [18].

Однією з основних психологічних особливостей діалогічного мовлення є його ситуативність $[5,6,8,9,15$, $19,22]$. Діалогічне мовлення є виключно ситуативним, оскільки його зміст може бути зрозумілим часто з урахуванням тієї ситуації, в якій відбувається мовлення.

Як зазначає Ю. Пассов, самі зовнішні обставини ситуації можуть у момент мовлення не бути наявними, проте вони є у свідомості комунікантів і обов'язково включені в ситуацію [15]. Обставинами виступають якісь минулі події, відомі лише співрозмовникам, їх переживання, життєвий досвід, спільні відомості тощо.

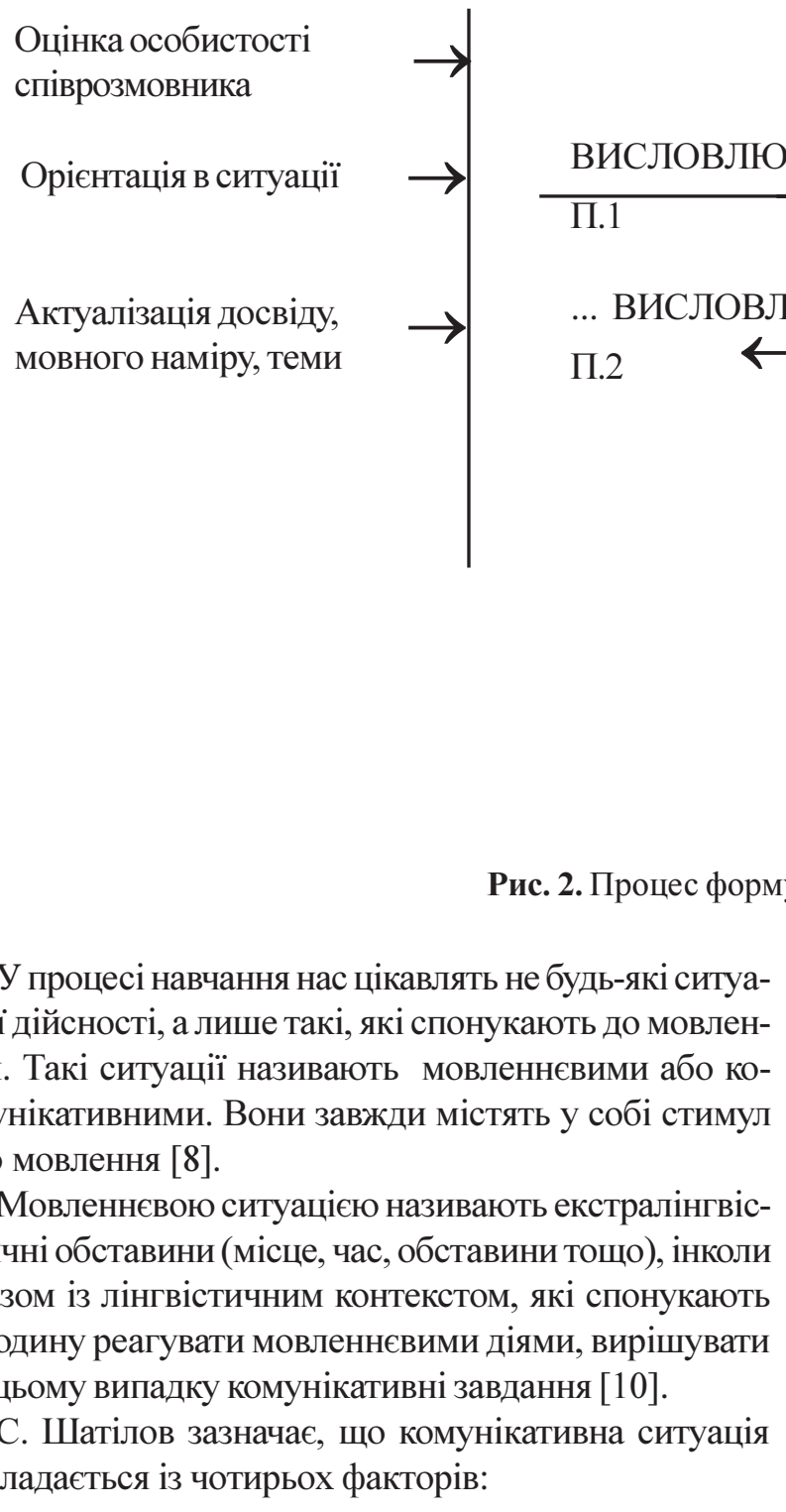

\footnotetext{
У процесі навчання нас цікавлять не будь-які ситуації дійсності, а лише такі, які спонукають до мовлення. Такі ситуації називають мовленнєвими або комунікативними. Вони завжди містять у собі стимул до мовлення [8].

Мовленнєвою ситуацією називають екстралінгвістичні обставини (місце, час, обставини тощо), інколи разом із лінгвістичним контекстом, які спонукають людину реагувати мовленнєвими діями, вирішувати у цьому випадку комунікативні завдання [10]. складається із чотирьох факторів:
}

Сприйняття

висловлювання

Оцінка особистості того, хто почав діалог

Оцінка ситуації

Аналіз висловлювання П.1

Актуалізація досвіду, намірів

Вибір варіанта реакціі
1. Обставини дійсності, в яких реалізується комунікація.

2. Відношення між комунікантами (суб'єктивна особистість співрозмовників).

3. Мовленнєве спонукання.

4. Реалізація самого акту спілкування, який створює нові обставини, стимул до мовлення [12].

Розрізняють природні та спеціально створені (або штучні) комунікативні ситуації. Перші виникають у мовленні самі собою, їх кількість надзвичайно обмежена і їх треба, без сумніву, використовувати у процесі навчання іноземної мови. Другі, у свою чергу, 
потребують певної деталізації зовнішніх обставин та умов, в яких має місце діалогічне спілкування, наявності вербального стимулу, визначення ролей, в яких комуніканти виступатимуть, стосунків між ними тощо [14].

Аналіз ситуації є орієнтовною основою мовленнєвих дій, і включає диференціацію, синтезування, виділення провідних ознак, які дозволять визначити програму мовленнєвої дії. Залежно від результатів орієнтації створюються різноманітні програми дій, які включають як стеоретипні елементи, так і їх нові комбінації, що відповідають цілям діяльності. Тому навчальні ситуації повинні являти собою сукупність саме основних, необхідних і достатніх опорних ознак, які з найбільш повною вірогідністю визначають можливу мовленнєву поведінку суб'єкта [6].

Ситуації повинні неодноразово повторюватись для того, щоб сформувати у студентів еталони провідних ознак ситуацій і способів поведінки у них [2]. Ці ознаки повинні обумовлювати перш за все основні компоненти змістової структури висловлювання (логікосмислові категорії диктального (інформуючого) чи модельного характеру, мовленнєві інтенції, тему), оскільки саме семантика, будучи предметом мовлення і зливаючись $з$ потребою у ній, породжує мотив [4], визначає мету висловлювання, являє собою осмислений суб'єктом результат мовленнєвої дії [2].

Згідно з результатами досліджень, проведених Т. Олійник [13] на автентичних навчальних матеріалах англійською, німецькою та російською мовами, найбільш поширеними є чотири основні функціональні типи діалогу:

1) діалог-розпитування. Він може бути одностороннім, коли один з партнерів запитує інформацію, а інший дає цю інформацію, та двостороннім, коли відбувається взаємний обмін інформацією. Двосторонній діалог-розпитування розвиває ініціативність обох партнерів, характерну для природного спілкування [11,21];

2) діалог-домовленість. Діалог-домовленість використовується при вирішенні співрозмовниками питання про плани та наміри, він є найбільш посильним для учнів. Після оволодіння діалогом-домовленістю здійснюється навчання змішаного типу діалогу: розпитування-домовленості;

3) діалог-обмін враженнями / думками. Мета цього типу діалогу - виклад свого бачення якогось предмета, події, явища, коли співрозмовники висловлюють свою думку, наводять аргументи для доказу, погоджуються з точкою зору партнера або спростовують іiі. При цьому ініціатива ведення бесіди є двосторонньою;
4) діалог-обговорення / дискусія. Мета такого діалогу полягає в тому, що співрозмовники прагнуть виробити якесь рішення, дійти певних висновків, переконати один одного у чомусь. Кожен функціональний тип діалогу характеризується певним набором діалогічних єдностей [11].

У всіх типах діалогів поширеною є діалогічна єдність “повідомлення - повідомлення" та їі варіанти, а у діалозі-обміні враженнями та у діалозі-обговоренні вона стоїть на першому місці [21]. Діалогдомовленість неможливо побудувати без діалогічної єдності спонукання - згода (відмова).

Згідно з програмою з дисципліни “Іноземна мова" для студентів вищих медичних закладів освіти студенти-медики повинні вміти самостійно диференціювати та аналізувати терміни і терміноелементи греколатинського походження; ідентифікувати та інтерпретувати граматичні структури у їх взаємозв'язку з семантичними особливостями тексту; використовувати загальну і наукову лексику при виконанні когнітивних завдань; застосовувати знання, отримані на заняттях з анатомії і латинської мови, в процесі вивчення англійської медичної термінології; здійснювати усно-мовленнєве спілкування (у монологічній і діалогічній формах) на ситуативно-зумовлену тематику; включити засвоєний лексико-граматичний матеріал в активне спілкування.

Найбільш типовими комунікативними завданнями $є$ : розпитати, попросити, запропонувати, повідомити, описати, розповісти, пояснити, оцінити, заперечити, обгрунтувати. 3 метою реалізації вищезазначених пунктів студенти-медики повинні оволодіти різними функціональними типами діалогів: діалогом-розпитуванням, діалогом-домовленістю, діалогом-обговоренням, діалогом-обміном враженнями тощо.

Студенти оволодівають різними типами діалогів на основі складної системи мовленнєвих навичок і вмінь, зумовлених лінгвістичними і психологічними особливостями діалогічного мовлення. Комунікативні навички і вміння формуються поетапно в процесі виконання студентами системи вправ.

Висновок. Важливою формою іншомовного мовлення студентів, якій приділяється увага в навчальному процесі вищих медичних навчальних закладів, $€$ діалогічне мовлення, яке набуває вигляду дискусії або диспуту. Під час проведення дискусії або диспуту відбувається тематичне спілкування, спрямоване на те, щоб переконати співбесідника в правильності своєї позиції, діалог на професійному рівні та на професійно-спрямовану тематику, обговорення різних думок і позицій, взаємна критика гіпотез і пропозицій, 
їхнє обгрунтування та зміцнення, що приводить до формування нових знань і уявлень, сприяє набуттю комунікативного досвіду вирішення професійних завдань. Таким чином, дискусія та диспут виступають

\section{Списоклітератури}

1. Беляев Б. В. Очерки по психологии обучения иностранным языкам / Б. В. Беляев. - М. : Просвещение, 1965. $-227 \mathrm{c}$.

2. Божович Е. В. Диалогическая речь как цель и средство обучения английскому языку в V-VI классах / Е. В. Божович // Иностр. яз. в школе. - 1985. - № 2. - С. 34-39.

3. Жинкин Н. И. Механизмы речи / Н. И. Жинкин. М. : Изд-во АПН РСФСР, 1958.-370 с.

4. Зимняя И. А. Психологические аспекты обучения говорению на иностранном языке / И. А. Зимняя. - М. : Просвещение, 1978.-159 с.

5. Кирилова Е. П. Пособие по практике устной речи (на материале фотографий) / Е. П. Кирилова, Б. Т. Лазарева. М. : Просвещение, 1986. -80 с.

6. Леонтьев А. Н. Деятельность, сознание, личность / А. Н. Леонтьев. -2-е изд. - М. : Политиздат., 1977. -352 с.

7. Ляховицкий М. В. Методика обучения иностранным языкам в средней школе / М. В. Ляховицкий. - М. : Высш. школа, 1982. -372 с.

8. Маркова А. К. Формирование мотивации учения в школьном возрасте: [пособие для учителя] / А. К. Маркова. -М. : Просвещение, 1984. - 96 с.

9. Мильруд Р. П. Современные концептуальные принципы коммуникативного обучения иностранным языкам / Р. П. Мильруд, Н. Р. Максимова // Иностр. яз. в школе. 2000.-№ 5. - С. 17-22.

10. Методика обучения иностранным языкам в средней школе / под ред. Н. И. Гез, М. В. Ляховицкого, А. А. Миролюбова и др. - М. : Высш. школа, 1982. -373 с.

11. Методика навчання іноземних мов у середніх навчальних закладах: [підручник] / кол. авторів під кер. С. Ю. Ніколаєвої. - К. : Ленвіт, 1999. - 320 с. не лише методом організації комунікативної взаємодії студентів, а й засобом формування професійної компетентності майбутнього фахівця.

12. Методика преподавания английского языка в средней школе / под ред. С. П. Шатилова. - М. : Ленинград, 1996. $-248 \mathrm{c}$.

13. Олійник Т. І. Рольова гра у навчанні англійської мови / Т. І. Олійник. -К. : Освіта, 1992.-127 с.

14. Основы методики преподавания иностранных языков : [учебник] / под ред. В. А. Бухбиндера, В. Штрауса. К. : Высш. школа, 1986. -335 с.

15. Очерки методики обучения устной речи на иностранных языках / под ред. В. А. Бухбиндера. - К. : Вища школа, 1980. -247 с.

16. Панова П. С. Обучение иностранному языку в школе / П. С. Панова. -К. : Рад. школа, 1989.- 142 с.

17. Пассов Е. И. Основы коммуникативной методики обучения иноязычному общению / Е. И. Пассов. - М. : Рус. язык, 1989. - 127 с.

18. Рогова Г. В. Методика обучения иностранным языкам в средней школе / Г. В. Рогова, Ф. М. Рабинович, Т. Е. Сахарова. - М. : Просвещение, 1991.-287 с.

19. Розенбаум Е. М. Основы обучения диалогической речи на языковом факультете педагогических вузов / Е. М. Розенбаум. - М. : Высшая школа, 1975. - 126 с.

20. Скалкин В. А. Коммуникативные упражнения на английском языке: [пособие для учителя] / В. А. Скалкин. М. : Просвещение, 1983.- 128 с.

21. Скляренко Н. К. Обучение речевой деятельности на английском языке в школе / Н. К. Скляренко. -К. : Рад. школа, 1988. $-150 \mathrm{c}$.

22. Littlewood W. Communicative Language Teaching / W. Littlewood. - Cambridge : Cambridge Univ. Press, 1991.$108 \mathrm{p}$.

23. Norman D. Communicative Ideas / D. Norman, U. Levihn, J. Anders. - London, 1986. - 155 p. 